\title{
Evaluation of a Warning System for Controlling Primary Infections of Grapevine Downy Mildew
}

\author{
T. Caffi and V. Rossi, Institute of Entomology and Plant Pathology, Università cattolica del Sacro Cuore, Piacenza, I \\ 29100, Italy; and R. Bugiani, Plant Protection Service, Regione Emilia-Romagna, Bologna, I 40100, Italy
}

\begin{abstract}
Caffi, T., Rossi., V., and Bugiani, R. 2010. Evaluation of a warning system for controlling primary infections of grapevine downy mildew. Plant Dis. 94:709-716.

A warning system based on (i) a model that simulates the development of all cohorts of Plasmopara viticola oospores, from oospore germination to infection; (ii) short-term weather forecasts; and (iii) a mobile phone short message system was tested in Northern Italy, from 2006 to 2008. An unsprayed control was compared with a "Warning A" treatment (WA, fungicides were applied whenever the warning system predicted an infection period), a "Warning B" treatment (WB, fungicides were applied as in the WA treatment but only when the relative dimension of any oospore cohort predicted by the model exceeded a threshold), and a "grower" treatment (fungicides were applied according to a conventional schedule). Average disease incidence on leaves was reduced by up to $90 \%$ in sprayed plots compared with unsprayed plots. On bunches, efficacy was always $>90 \%$ at fruit set; when most berries were touching, efficacy was higher for the WA (96\%) than for grower (89\%) and WB (85\%) treatments. On average, 6.8 fungicide sprays were applied following the grower's schedule; use of the warning system reduced applications by about one-half (WA treatment) or two-thirds (WB treatment). The grower's schedule had an average cost of $337 € /$ ha; the average saving with the WA and the WB treatments was 174 and $224 € /$ ha, respectively.
\end{abstract}

Downy mildew of grapevine, caused by the oomycete Plasmopara viticola (Berk. \& M.A. Curtis) Berl. \& De Toni, is potentially destructive and requires control with fungicides under European grape-growing conditions, which are characterized by high humidity and abundant rainfall in spring. In northern Italy, several fungicide applications are used to control the disease and are generally applied following a calendar schedule with preventative fungicides every 7 to 14 days, depending on the fungicides used (5). Some of these sprays are usually unnecessary given the sporadic occurrence of severe disease outbreaks. Because of the high cost of calendar-based spray programs and the desire to reduce pesticide levels in the environment, considerable efforts have been made to develop disease prediction or warning systems for downy mildew of grapevine.

Several models, including EPI (49), POM (51), Plasmopara Risk Oppenheim (19), PLASMO (35,39), and SIMPO (20), have been validated under a wide range of environmental conditions in Italy; however, none was sufficiently accurate or robust to be used for scheduling fungicide

Corresponding author: T. Caffi

E-mail: tito.caffi@unicatt.it

Accepted for publication 14 February 2010.

doi:10.1094/PDIS-94-6-0709

(C) 2010 The American Phytopathological Society applications against downy mildew $(9,10,53,54)$. As a consequence, growers continue to follow the simple and widely known "3-10" empirical rule for deciding when to begin the spraying season, and they then continue the protection with a calendar-based schedule (42). The 3-10 rule is based on the simultaneous occurrence of the following conditions: (i) air temperature equal to or greater than $10^{\circ} \mathrm{C}$, (ii) vine shoots at least $10 \mathrm{~cm}$ long, and (iii) a minimum of $10 \mathrm{~mm}$ of rainfall in 24 to $48 \mathrm{~h}(1)$.

This management strategy is based on the traditional concept of the pathogen life cycle, where a downy mildew epidemic begins with a restricted number of oospores that germinate in a narrow time interval, and the explosive increase of the epidemic is driven by massive clonal multiplication causing secondary infections (26). Recent studies (17), however, demonstrated a continuous input of new genotypes to the epidemic during a prolonged period from May to August, each contributing one or a few lesions to the total disease severity, and only one or two genotypes per epidemic undergoing secondary cycles to generate a high number of progeny $(16,23,44)$. It follows that, in addition to triggering downy mildew epidemics, oospores also play an ongoing role in their development.

These recent findings on the $P$. viticola life cycle have been incorporated in a new model developed by Rossi et al. (40). This weather-driven, mechanistic, and dynamic model simulates the development of each oospore cohort during the primary inoculum season, including oospore germination; production and survival of sporangia; release, survival, and dispersal of zoospores; and infection and incubation. In validation tests conducted in 100 vineyards in northern, southern, and insular Italy (1995 to 2007) and with potted grapevine plants exposed to inoculum (2006 to 2008), the new model was found to have high sensitivity, specificity, and accuracy; the true positive proportions (TPPs) and true negative proportions (TNPs) of predictions were TPP $=0.99$ and $\mathrm{TNP}=0.87$, respectively (8).

The model of Rossi et al. (40) was elaborated according to the principles of systems analysis (27) and was evaluated by Caffi et al. (8). However, this model has not been thoroughly tested in the field to determine whether its predictions of downy mildew primary infections can be used to efficiently manage this disease. Thus, a disease warning system (14) based on the new model and on short-term weather forecasts was developed and its use was evaluated in experimental vineyards over a 3-year period in northern Italy. For each vineyard, the number of fungicide spray applications and the disease intensity were compared for treatments following the recommendations of the warning system with treatments following a standard grower's fungicide schedule and with an unsprayed control.

\section{MATERIALS AND METHODS}

Disease warning system. The warning system included three components: (i) weather data, (ii) a mathematical model, and (iii) a mobile phone short message service (SMS). The weather data were the official data of the Agro-Meteorological Service of the Emilia-Romagna Region (http://www.arpa.emr.it/sim/); accuracy of these data has been widely recognized $(6,37)$. These data concern hourly values of air temperature $\left(\mathrm{T}\right.$, in $\left.{ }^{\circ} \mathrm{C}\right)$, relative humidity $(\mathrm{RH}$, in \%), rain $(\mathrm{R}$, in $\mathrm{mm})$, and presence of wetness (W, yes or no) for each node of the grid ( 5 by $5 \mathrm{~km}$ ) that covers the region (6). For each node, data until 24:00 $\mathrm{h}$ of the previous day and weather forecasts for the current day and the next 2 days were used. The regional system calculates data until 24:00 h through a complex method of interpolation based on a network of stations, a meteoro- 
logical radar, and a topographic elevation database (6); hourly forecasts of T, RH, R, and $\mathrm{W}$ for a 72 -h time range are calculated using the Consortium for Small-scale Modelling Limited Area Model Italy (COSMO-LAMI) model (48) developed in the framework of the COSMO Consortium (http://www.cosmo-model.org/). Data for the nodes corresponding to the geographical coordinates of the experimental vineyards were downloaded from the official website each morning between 15 April and 30 June and used for operating the mathematical model.

The model used in this study predicts the occurrence of downy mildew infection periods during the primary inoculum season. The model defines a primary inoculum season and a seasonal oospore dose, divides this dose into many coeval cohorts of oospores, and defines the relative density of each oospore cohort. Development of each cohort is split into different state variables, in which changes from one state to another are regulated by rates depending on environmental conditions. The oospores belonging to the same cohort simultaneously progress along the primary infection cycle (production and survival of sporangia; release, survival, and dispersal of zoospores; infection and appearance of disease symptoms), with a time step of $1 \mathrm{~h}$. Therefore, the model can be used to predict the time when any oospore cohort results in a downy mildew infection.

The model was used to determine the beginning and end of the primary inoculum season. Within this time period, the model was operated each morning using the data until 24:00 $\mathrm{h}$ of the previous day and the weather forecasts. Therefore, two kinds of model outputs were calculated on the current day t: calculated output for day $\mathrm{t}-1$ and predicted output for days $t, t+1$, and $t+2$. As a consequence, two kinds of alarms were provided: infection period already occurred on $\mathrm{t}-1$ and infection period which will occur on day $t$ to $t+2$. Accuracy of predicted output was assessed as follows: (i) an infection period was predicted by using the weather forecasts and was confirmed a posteriori by using the hindcast weather data estimates, (ii) an infection period was predicted but not confirmed by the hindcast weather data estimates, and (iii) an infection period was not predicted but was calculated a posteriori using the hindcast weather data estimates.

For either calculated or predicted infection periods, an SMS was sent to the mobile phone of the managers of the experimental vineyards. Two kinds of SMSs were sent: "a downy mildew infection period is predicted for the day $n+\mathrm{t}$ ", and "a not previously predicted infection period occurred on the day $n$ " (usually the previous day). Possible secondary infections caused by the asexual sporangia of $P$. viticola, which may be produced on the downy mildew lesions, were not considered for producing warnings.

Field experiments. Experiments were carried out at three locations in EmiliaRomagna (northern Italy) that were topographically and climatically favorable to the pathogen (42): Castelfranco Emilia, Mandriole, and Camerlona. The Castelfranco vineyard was in the central Po Valley $\left(44^{\circ}\right.$ $34^{\prime} 30^{\prime \prime} \mathrm{N}, 11^{\circ} 03^{\prime} 02^{\prime \prime} \mathrm{E}, 46 \mathrm{~m}$ in altitude) and contained cv. Trebbiano Toscano vines that were 10 years old in 2006 and trained with a permanent cordon system with spur pruning. The Mandriole vineyard was in the eastern Po Valley $\left(44^{\circ} 33^{\prime} 01^{\prime \prime} \mathrm{N}, 12^{\circ}\right.$ $13^{\prime} 32^{\prime \prime} \mathrm{E}$, at sea level) and contained cv. Trebbiano vines that were 21 years old in 2006 and trained according to the Sylvoz system. The Camerlona vineyard was in the eastern Po Valley $\left(44^{\circ} 26^{\prime} 51^{\prime \prime} \mathrm{N}, 12^{\circ}\right.$ $07^{\prime} 34^{\prime \prime} \mathrm{E}$, at $1 \mathrm{~m}$ above sea level) and contained cv. Pinot Blanc vines that were 14 years old in 2008 and trained on a Geneva Double Curtain system. The withinrow and between-row spacing was 2 by 3.5 $\mathrm{m}$ for the first two vineyards and 1 by $4 \mathrm{~m}$ for the third vineyard.

The three cultivars used in these experiments are highly sensitive to downy mildew $(13,33)$. The vineyards were managed following standard practices except as indicated for fungicides. Powdery mildew was controlled, when necessary, with appropriate fungicides (not effective against downy mildew). For downy mildew control, the following four treatments were compared: (i) vines were unsprayed (hereafter referred to as the "unsprayed" treatment); (ii) vines were sprayed when the warning system predicted an infection

Table 1. Commercial products, active substances used for the control of downy mildew of grapes in the different strategies

\begin{tabular}{lllll}
\hline Product & Commercial name & \multicolumn{1}{c}{ Active ingredients (a.i.) } & \%a.i. & Manufacturer \\
\hline A & Forum MZ WG & Mancozeb + Dimethomorph & $60+9$ & BASF \\
B & Forum Gold & Dithianon + Dimethomorph & $35+15$ & BASF \\
C & Forum 50 WP & Dimethomorph & 50 & BASF \\
D & Cabrio Top & Metyram + Pyraclostrobin & $55+5$ & BASF \\
E & Forum R & Copper oxychloride + Dimethomorph & $40+6$ & BASF \\
F & Melody Compact & Copper oxychloride + Iprovalicarb & $35.6+4.9$ & Bayer \\
G & Vondozeb DG & Mancozeb & 75 & Cerexagri \\
H & Poltiglia Disperss & Cupro sulfate & 20 & Cerexagri \\
I & Dithane DG & Mancozeb & 75 & DOW \\
L & Ridomil Gold MZ & Mancozeb + Metalaxil-m & $64+3.9$ & Syngenta \\
\hline
\end{tabular}

period using weather forecasts or calculated an infection period using hindcast weather data estimates (i.e., a posteriori), and at least 7 days had elapsed since the previous fungicide application (hereafter referred to as the "Warning A" treatment; WA); (iii) vines were sprayed as in WA but only if the oospore cohort that caused infection (either predicted or calculated) represented at least $2 \%$ of the seasonal oospore dose (hereafter referred to as the "Warning B" treatment; WB); and (iv) vines were sprayed according to the grower's schedule (hereafter referred to as the "grower" treatment). The treatments were arranged in a complete randomized block design, with four replicate plots; each plot consisted of three rows, with six plants per row. Six independent field experiments were conducted. Experiments were conducted in the Castelfranco vineyard in 2006, 2007, and 2008; in the Mandriole vineyard in 2006 and 2007; and in the Camerlona vineyard in 2008. For experiments conducted in the same vineyard, entirely different subplots of vines were used in different years, in order to guarantee a representative dose of overwintering inoculum.

For the WA and WB treatments, sprays were made using dimethomorph as a preventative application (commercial product at $250 \mathrm{~g} / \mathrm{hl}$ of water) when sprays were applied within the date signaled in the SMS warning and as a curative application (at $350 \mathrm{~g} / \mathrm{hl}$ of water) when sprays were applied after the date recommended by model output. Curative sprays were also applied when an infection period was calculated on day $n$ but had not been predicted for day $n$ using the weather forecast. For the grower treatment, different plant protection products were used (Table 1) according to each grower's schedule (Table 2). All of these products are considered effective for controlling downy mildew in northern Italy $(7,32)$ and were used at the label rates.

Plant protection products were applied with a knapsack airblast sprayer SR 420 (Stihl Inc., Virginia Beach, VA), which ensured an even distribution on the whole plot. Depending on the trellis system and growth stage of the vines, water with product was applied at 4 to $8 \mathrm{hl} / \mathrm{ha}$ (ha $=$ $10,000 \mathrm{~m}^{2}$ ).

Disease assessment. From mid-April, the vineyards were inspected twice a week to detect the first downy mildew lesions. Disease severity was assessed on a sample of 100 random leaves and 100 bunches per plot, taken on both sides of the central rows (i) when inflorescences were clearly visible (growth stage [GS] 53 of the $\mathrm{BBCH}$ scale; 1), (ii) at fruit set (GS 71), and (iii) when the majority of berries were touching (GS 79). The leaves and the bunches were not necessarily the same for the three assessment times. Leaves and bunches were carefully observed for downy mildew lesions and classified as 
heathy or affected, and disease incidence was calculated as a percentage of affected leaves (or bunches). When infection was heavy in the untreated plots (i.e., $>20 \%$ of incidence), the percentage of area occupied by downy mildew was estimated using the EPPO scale for leaves (12) and the scale shown in Figure 1 for bunches (only at GS 71 and 79). Disease intensity (as a percentage) was then calculated as average disease severity on all the sampled leaves (or bunches).

Data analysis. Data for disease incidence and intensity were arcsine transformed to make variances uniform and then subjected to the one-way analysis of variance for a completely randomized block design, with four replicates. A separate analysis was done for each disease assessment time in each experiment. The Fisher protected least square difference test was used at $P=0.05$ to separate means.

The efficacy of fungicide treatments was determined based on mean disease incidence on leaves and bunches using the formula $E=100-[(Y t / Y u) \times 100]$, where $E$ is the efficacy of the treatment and $Y t$ and $Y u$ are disease incidence on leaves or bunches in sprayed and unsprayed plots, respectively.

The different treatments (WA, WB, and grower) were also compared on the basis of costs directly related to the fungicide applications. The costs, calculated in euros per hectare, included fungicide purchase, fuel consumption, and human labor. Based on the data of Massetti et al. (31), costs of the fungicides were $8 € / \mathrm{ha}$ for the dithiocarbamates, $10 € /$ ha for the copper compounds, and $25 € /$ ha for the other systemic fungicides. Fuel consumption was $4.9 € /$ ha per application $(0.7 € /$ liters of fuel, 7 liters/ha per application), and human labor was $14 € /$ ha (14 $€ /$ h of labor, $1 \mathrm{~h} /$ ha per application). The costs of the warning system were not considered. Fixed costs for setting up and maintaining the warning system were paid by the Plant Protection Organisation of the EmiliaRomagna region, which produces free warnings for advisors and growers; the additional cost for sending SMS messages was small and not included.
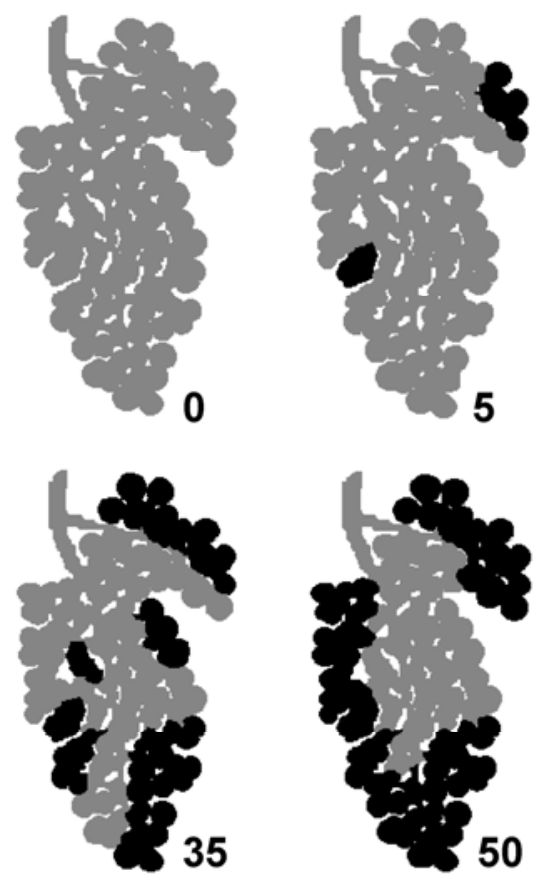

Fig. 1. Diagram used for assessing severity of downy mildew symptoms on grape bunches. The drawing of the bunch is from the BBCH scale for the growth stage 71 (1) (i.e., fruit set). Disease severity is expressed as a percentage of the black area (affected) over the total area of the bunch; areas were measured using the software Assess 2.0 (Image Analysis Software for Plant Disease Quantification, American Phytopathological Society Press, St. Paul, MN).

\section{RESULTS}

Disease warnings. Examples of disease warnings are presented in Figure 2 for the Castelfranco vineyard. In 2006 (Fig. 2A), based on weather forecasts, the warning system provided four alarms: 29 April, 24 May, 1 June, and 7 June. Following these alarms, fungicides were applied on 30 April, 24 May, and 1 June in the WA treatment. The alarm sent on 7 June was disregarded because the fungicide applica-
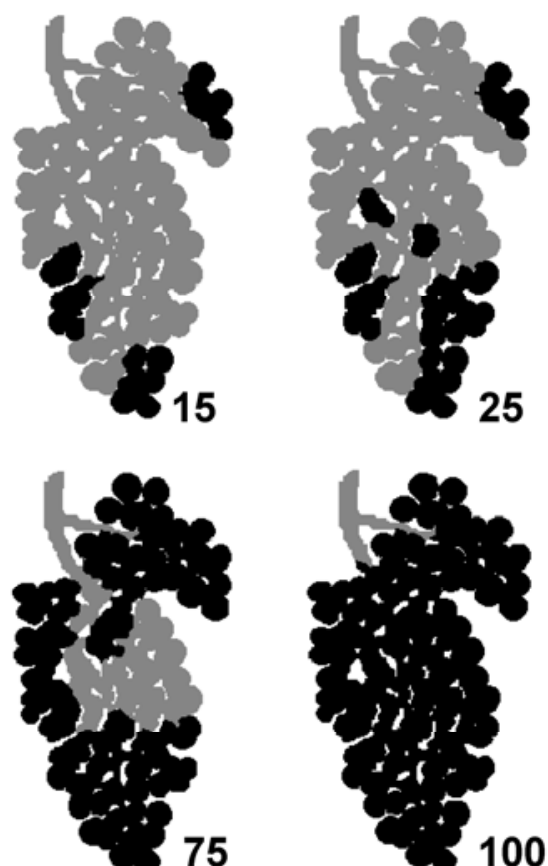

Table 2. Date of spray applications in experiments testing the warning system for downy mildew of grapes and products used

\begin{tabular}{|c|c|c|c|c|c|c|c|c|c|}
\hline Experiment, treatment $\mathbf{y}^{\mathrm{y}}$ & & & & tes of fungic & e sprays anc & ungicides $\mathbf{u}$ & & & \\
\hline Castelfranco 2006 & & & & & & & & & \\
\hline Warning A & 30 April A & 24 May A & 1 June A & $\ldots$ & $\ldots$ & $\ldots$ & $\ldots$ & $\ldots$ & $\ldots$ \\
\hline Warning B & $\ldots$ & 24 May A & 1 June A & $\ldots$ & $\ldots$ & $\ldots$ & $\ldots$ & $\ldots$ & $\ldots$ \\
\hline Grower & 26 April I & 02 May I & 7 May A & 18 May A & 28 May A & 7 June $\mathrm{H}$ & $\ldots$ & $\ldots$ & $\ldots$ \\
\hline Castelfranco 2007 & & & & & & & & & \\
\hline Warning A & 30 April E & 26 May E & 11 June E & $\ldots$ & $\ldots$ & $\ldots$ & $\ldots$ & $\ldots$ & $\ldots$ \\
\hline Warning B & & 26 May E & 11 June E & & & $\ldots$ & $\ldots$ & $\ldots$ & $\ldots$ \\
\hline Grower & 28 April I & 3 May I & 9 May A & 21 May A & 31 May A & 10 June A & $\ldots$ & $\ldots$ & $\ldots$ \\
\hline Castelfranco 2008 & & & & & & & & & \\
\hline Warning A & 12 May E & 21 May C & 30 May C & 12 June $\mathrm{E}$ & $\ldots$ & $\ldots$ & $\ldots$ & $\ldots$ & $\ldots$ \\
\hline Warning B & & 21 May C & 30 May C & 12 June $\mathrm{E}$ & $\ldots$ & $\ldots$ & $\ldots$ & $\ldots$ & $\ldots$ \\
\hline Grower & 24 April I & 10 May I & 16 May A & 23 May A & 01 June A & 10 June $\mathrm{H}$ & 16 June $\mathrm{H}$ & $\ldots$ & $\ldots$ \\
\hline Mandriole 2006 & & & & & & & & & \\
\hline Warning A & 26 April A & 10 May A & 25 May A & 07 June A & $\ldots$ & $\ldots$ & $\ldots$ & $\ldots$ & $\ldots$ \\
\hline Warning B & & 10 May A & 25 May A & 07 June A & $\ldots$ & $\ldots$ & $\ldots$ & $\ldots$ & $\ldots$ \\
\hline Grower & 28 April G & 3 May A & 9 May A & 21 May A & 31 May D & 10 June L & $\ldots$ & $\ldots$ & $\ldots$ \\
\hline Mandriole 2007 & & & & & & & & & \\
\hline Warning A & 25 May A & $\ldots$ & $\ldots$ & $\ldots$ & $\ldots$ & $\ldots$ & $\ldots$ & $\ldots$ & $\ldots$ \\
\hline Warning B & 25 May A & $\ldots$ & $\ldots$ & $\ldots$ & $\ldots$ & $\ldots$ & $\ldots$ & $\ldots$ & $\ldots$ \\
\hline Grower & 26 April G & 2 May A & 9 May A & 17 May A & 31 May D & 09 June L & 16 June D & $\ldots$ & $\ldots$ \\
\hline Camerlona 2008 & & & & & & & & & \\
\hline Warning A & 18 April A & 30 April A & 16 May A & 30 May A & 13 June A & $\ldots$ & $\ldots$ & $\ldots$ & $\ldots$ \\
\hline Warning B & $\ldots$ & $\ldots$ & 16 May A & 30 May A & 13 June A & $\ldots$ & $\ldots$ & $\ldots$ & $\ldots$ \\
\hline Grower & 22 April B & 29 April B & 8 May H & 20 May B & 26 May H & 04 June B & 10 June $\mathrm{F}$ & 16 June $\mathrm{F}$ & 23 June L \\
\hline
\end{tabular}

${ }^{\mathrm{y}}$ Experiments included an untreated control.

${ }^{\mathrm{z}}$ Commercial products A to $\mathrm{L}$ are listed in Table 1. 
tion of 1 June already protected plants from this predicted infection. In the WB treatment, the first warning was ignored because the correspondent cohort of oospores was $<2 \%$ of the seasonal oospore dose; therefore, fungicides were applied only two times (Table 1). When the disease model was operated using the hindcast estimates, there was only one predicted infection period, on 1 June. This model prediction was accurate, because the downy mildew symptoms were first observed on 16 June (i.e., within the time period predicted by the model; Fig. 3A).

In the Castelfranco vineyard in 2007 (Fig. 2B), the warning system produced three alarms. Consequently, fungicides were applied three and two times in the WA and WB treatments, respectively (Ta- ble 2). When the model was operated using real meteorological data, all of these alarms that resulted from weather forecasts resulted in prediction of infection. Disease symptoms, in the untreated plot, were first recorded on 16 June, in agreement with the infection predicted on 12 June; therefore, the two earlier model predictions were wrong and the corresponding alarms were unjustified.

In the Castelfranco vineyard in 2008 (Fig. 2C) and based on weather forecasts, there were nine alarms between 12 May and 18 June, which resulted in four fungicide applications in the WA treatment and three in the WB treatment (Table 1). The alarm sent on 7 June was ignored because the rainy period between 2 and 8 June (29.8 $\mathrm{mm}$ of rain in total) made it impossi-

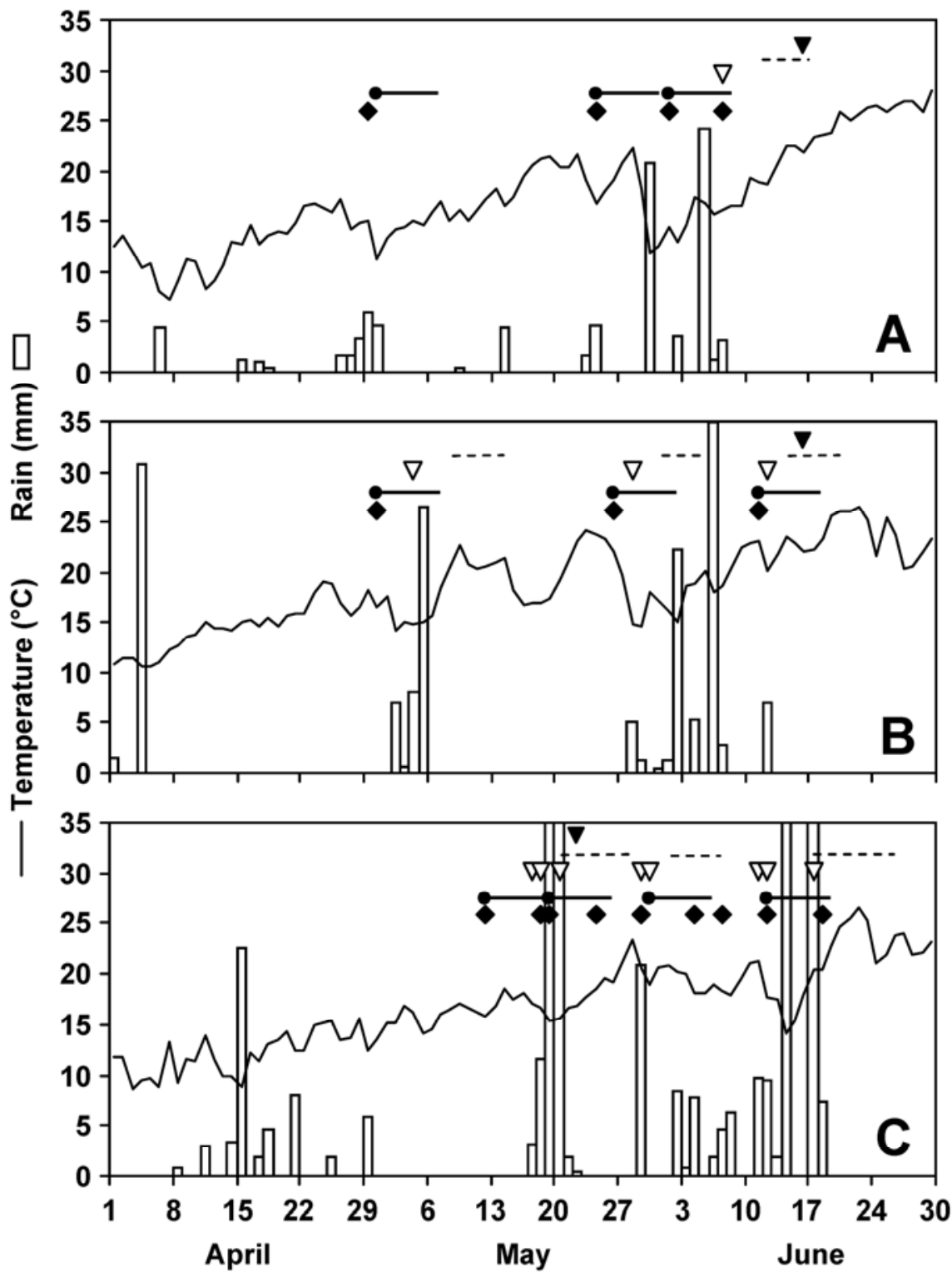

Fig. 2. Examples showing alarms provided by the warning system operated using 72 -h weather forecasts $(\bullet)$, time when fungicides were applied in the Warning A treatment $(\bullet)$, estimated period of protectant activity of any fungicide application (solid line), prediction of infection $(\nabla)$, disease onset (dotted line) produced by the model operated using measured weather data, and actual disease onset ( $\mathbf{\nabla}$ ) for the Castelfranco vineyard in A, 2006; B, 2007; and C, 2008. The line and the bars represent the measured temperature and rainfall, respectively. ble to spray with a tractor-operated sprayer. When the model was run using the hindcast data, it predicted the occurrence of eight infection periods, clustered in four periods: 17 to 20 May, 29 and 30 May, 11 and 12 June, and 17 June (Fig. 3B). The disease was first noticed at the end of incubation of the first infection period.

On the whole, in this vineyard over the 3 years, the number of warnings made by using the weather forecasts was greater than the number of infection periods predicted by running the model $a$ posteriori (i.e., by using forecast rather than hindcast weather data). In the six data sets (one data set for each of the six field experiments), $40 \%$ of the alarms based on weather forecasts were not confirmed by the actual weather data (data not shown).

Disease control. At Castelfranco in 2006, the first downy mildew symptoms appeared on 16 June. On 30 June, $7 \%$ of the leaves of the unsprayed control were affected while bunches were disease free (Table 3). Six applications were performed following the grower's schedule, and neither leaves nor bunches were affected. The same results were obtained following the disease warning system, with only three sprays in the WA treatment and two in the WB treatment.

The results at Castelfranco in 2007 were similar to those of 2006. The disease appeared in mid-June with $10 \%$ of leaves and $4 \%$ of bunches showing trace symptoms in the unsprayed plots. Six, three, and two sprays were applied in the grower, WB, and WA treatments, respectively, which were all disease free at mid-June.

In the Castelfranco vineyard in 2008, the environmental conditions were highly favorable for the pathogen, with repeated rain events between mid-May and midJune. The first symptoms appeared on 22 May, and the disease rapidly increased until $75.8 \%$ of leaves and $52.0 \%$ of bunches were affected in the unsprayed plots 1 month later, with average disease intensity of 11.5 and $2.9 \%$, respectively. The seven fungicide sprays applied in the grower treatment reduced the disease incidence to $3.5 \%$ and the intensity to trace levels on leaves, while the bunches were disease free. Disease levels did not significantly differ in the grower and WA treatments, even though the WA treatment called for only four sprays. In the WB treatment, fungicides were not applied on 12 May (i.e., the first spray in the WA treatment); this resulted in $26.9 \%$ of the bunches affected (disease intensity on bunches was $0.5 \%$ ) because plants were not protected against the infections on 18 and 19 May (Fig. 3B).

At Mandriole in 2006, the first disease symptoms were observed in early May, caused by repeated infections that were correctly predicted by the disease model between 27 and 30 April (data not shown). By mid-June, the disease was already se- 
vere on the unsprayed control, with $53.0 \%$ of leaves affected; at the end of June, disease incidence was $69.3 \%$ on leaves and $23.3 \%$ on bunches (Table 3 ). In both WA and WB plots, disease incidence was significantly lower than in the untreated ones ( $16.0 \%$ on leaves and $0.9 \%$ on bunches, as average of the two treatments). Following the grower's schedule, $34 \%$ of leaves and $9.0 \%$ of bunches were affected. The latter value was significantly higher than that in the plots sprayed according to the alarms produced by the warning system, even though more sprays were applied in the grower treatment than in both the WA or WB treatments. The grower used the protectant fungicide Vandozeb (a.i. mancozeb) on 28 April, while both the warning systems' treatments used Forum MZ (a.i. dimethomorph + mancozeb) on 26 April. As previously mentioned, repeated infections likely occurred on 27 to 30 April.

At Mandriole in 2007, downy mildew was almost absent, with only $1 \%$ of leaves affected in the unsprayed plots in late June (Table 3). Fungicides were applied seven times in the grower treatment and only once in the WA and WB treatments (Table 2).

At Camerlona in 2008, downy mildew caused severe epidemics. In plots not protected with fungicides, the disease was already present on $3.7 \%$ of leaves at the end of April and, on 2 July, disease affected $87.3 \%$ of leaves $(37.3 \%$ intensity) and $95.3 \%$ of bunches (38.9\% intensity) (Table 3). In the grower treatment, nine fungicide applications limited disease incidence to $2.0 \%$ on leaves and $6.0 \%$ on bunches on 2 July. Similar results were obtained on bunches in the WA and WB treatments, which received five and three sprays, respectively (Table 3). In contrast, disease incidence on leaves was higher in both the warning systems' treatments than in the grower treatment.

Efficacy and costs of fungicide treatments. Compared with the unsprayed treatment, the other three treatments reduced disease incidence on both leaves and bunches in all the vineyards (Table 3 ). The six field experiments were performed under a range of conditions, including different years, cultivars, and locations. When the efficacy was analyzed at GS 79, efficacy in suppressing disease incidence on leaves ranged from $51.0 \%$ (for the grower treatment in Mandriole vineyard in 2006) to $100 \%$ (for all three treatments in the vineyards with light epidemics: Catelfranco in 2006 and 2007 and Mandriole in 2007). Average efficacy in reducing disease was greater than $90 \%$ for all three treatments.

In the four field experiments in which downy mildew affected bunches, efficacy for the three fungicide treatments was always $>90 \%$ at both GS 71 and GS 79 , with two exceptions for the latter growth stage: efficacy was only $48 \%$ for the WB treatment at Castelfranco in 2008 and only $61 \%$ for the grower treatment at Mandriole in 2006 (data not shown). Therefore, average efficacy on bunches at GS 79 was higher and more consistent for the WA treatment $(95.5 \pm 1.9 \%$ of efficacy) than for the grower $(88.8 \pm 9.2 \%)$ or the WB $(84.8 \pm 12.2 \%)$ treatments. Disease was suppressed with different numbers of fungicide applications. Compared with the average number of sprays in the grower treatment (average $=6.8$ ), the number of sprays was reduced by about one-half in the WA treatment and by about two-thirds in the WB treatment. Spray reduction was greater when the environmental conditions were unfavorable for $P$. viticola (as at Mandriole in 2007, where the warning system recommended six fewer sprays than the grower schedule) than when there were severe epidemics (as in 2008 at both locations and in 2006 at Mandriole, where the warning system recommended three fewer sprays on average than the grower schedule).

The grower spray schedule was the most expensive control strategy, averaging 337 $€ /$ ha, with a minimum of $262 € /$ ha in Cas- telfranco vineyard in 2006 and a maximum of $467 € /$ ha in Carmelona vineyard in 2008. The grower spray schedule did not change according to the disease level: for instance, in Castelfranco vineyard, the cost was higher in 2007 (317 €/ha) when there was no disease than in 2008 (297 €/ha) when the disease was severe. The two treatments based on the disease warnings were less costly, averaging $164 € /$ ha (range of 52 to $260 € / \mathrm{ha}$ ) for the WA treatment and $112 € /$ ha (range of 52 to $156 € /$ ha) for the WB treatment. The average saving was 174 and $224 € /$ ha for the two treatments, respectively, with the highest saving of 311 $€ /$ ha in the Mandriole vineyard in 2007, when the disease did not develop.

The warning system had no economic impact on the market value of the production because there was no significant difference between the bunch damage levels in the three treatments (WA, WB, and grower; Table 3).

\section{DISCUSSION}

Madden and Ellis (28) suggested that proper validation of a warning system should include comparison of the system-
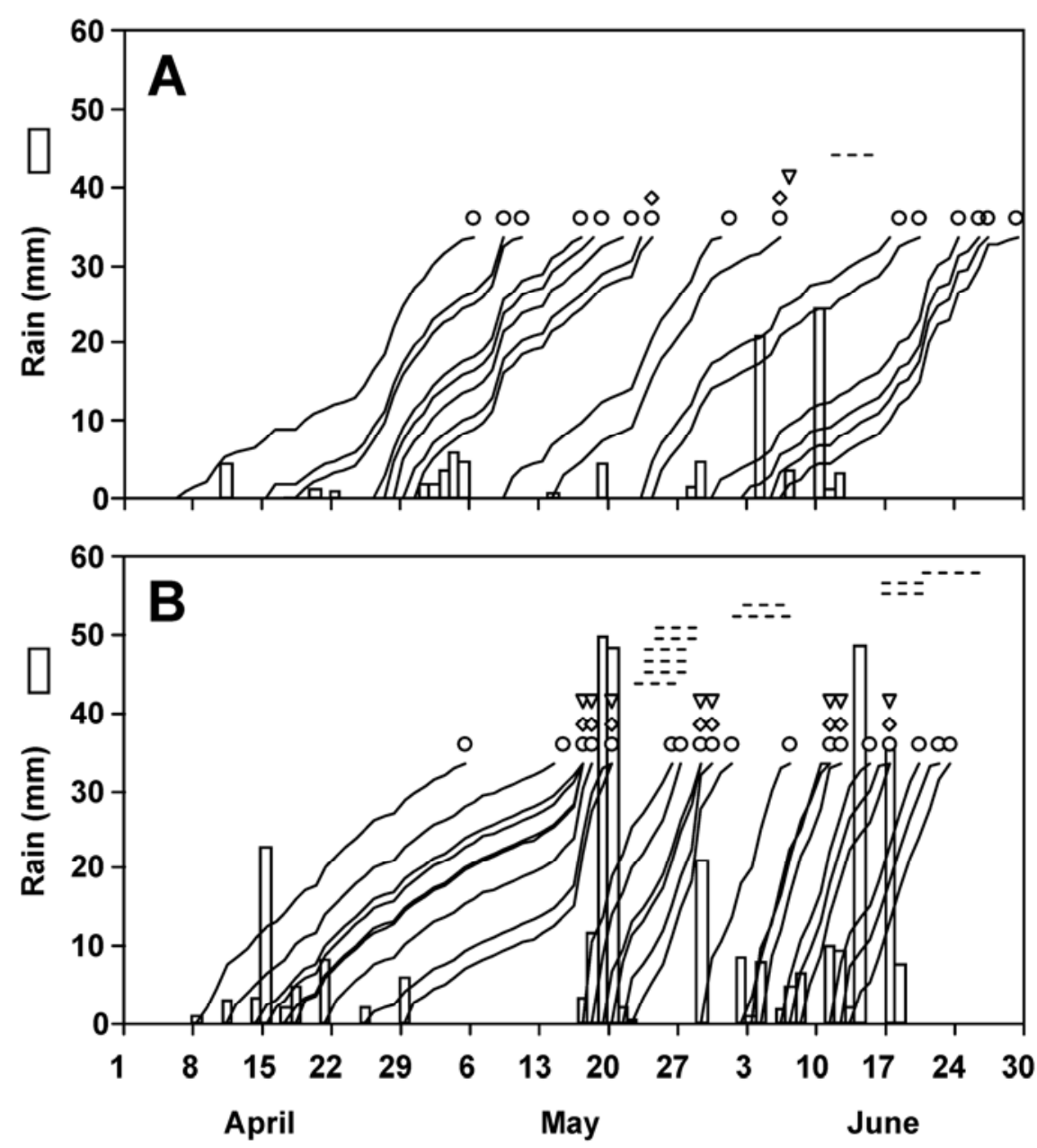

Fig. 3. Examples showing the output of the model simulating the development of the Plasmopara viticola oospores during the primary inoculum season in the Castelfranco vineyard in A, 2006 and $\mathbf{B}$, 2008. Solid line, germination course of any oospore cohort; $\bigcirc$, zoospore release; $\diamond$, zoospore dispersal; $\nabla$, infection; dotted line, predicted period of downy mildew onset. 
generated spray schedule with a standard spray schedule and a no-fungicide control. These suggestions were followed in the present study. The use of the warning system (as manifested in the WA and WB treatments) resulted in low disease incidence relative to the unsprayed control and similar incidence to that in the grower's treatment (Table 3), except in the Camerlona vineyard in 2008, where disease incidence (but not disease intensity) on leaves was lower in the plots sprayed according to the grower's schedule than in plots sprayed based on the warning system. In the Mandriole vineyard in 2006, moreover, disease incidence (but not disease intensity) on bunches was higher in the grower treatment than in the WA and WB treatments. This latter result may have been influenced by differences in the efficacy of the fungicides used in the treatments as well as difference in spray timing.

High levels of disease control were obtained with the three fungicide treatments (WA, WB, and grower) when disease pressure was either high (at Castelfranco and Camerlona in 2008) or moderate (at Man- driole in 2006); when the disease pressure was very low (at Castelfranco in 2006 and 2007), the control was complete. Even though the number of sprays varied considerably among experiments (i.e., 1 to 5), use of the warning system reduced the number of sprays from 33 to $86 \%$ in the six field experiments, with a median reduction of $54 \%$.

This warning system uses a model that predicts primary infection periods during the oosporic inoculum season (i.e., from mid-April to late June or early July under the conditions of the present work). Advisories are then produced to protect vines from primary infections, even though both primary and secondary infections occur during this period (41). Nevertheless, the disease was effectively managed. The environmental requirements for oosporic germination and infection differ from than those for secondary infection and, moreover, they might be met more frequently than those for secondary infection (23).

Some prediction or warning systems for downy mildew considered only the secondary infections $(11,29,35)$, whereas others
$(30,36)$ incorporated the oospore component and explicitly considered both primary and secondary infections. The basis for the efficient disease control achieved by our warning system, which focuses on primary infections, only becomes clear with consideration of recent population genetics studies of $P$. viticola epidemics $(16,23,24,44,45)$. These studies showed that oosporic infections massively occur throughout the epidemic, and that only one or two genotypes per epidemic are able to generate a large number of offspring at the vineyard scale whereas most genotypes only generate a few lesions each. Dominant genotypes characterized by high multiplication potential are usually the first that colonize vines early in the season and, consequently, prevention of early disease is crucial for disease management (15). Therefore, the efficient control of oosporic infections achieved by our warning system may prevent dominant genotypes from establishing in the vineyard.

The warning system used in this study could be improved by reducing the unjustified alarms produced by the disease model.

Table 3. Number of fungicide sprays and incidence of affected leaves and bunches in different growth stages (GSs) in experiments (Exp.) testing the warning system for downy mildew of grape ${ }^{w}$

\begin{tabular}{|c|c|c|c|c|c|c|c|}
\hline \multirow[b]{3}{*}{ Exp., treatment ${ }^{y}$} & \multirow[b]{3}{*}{ Sprays ${ }^{\mathrm{z}}$} & \multicolumn{6}{|c|}{ Disease incidence (disease intensity) ${ }^{x}$} \\
\hline & & \multicolumn{3}{|c|}{ Leaves } & \multicolumn{3}{|c|}{ Bunches } \\
\hline & & GS 53 & GS 71 & GS 79 & GS 53 & GS 71 & GS 79 \\
\hline Castelfranco 2006 & & 26 April & 9 June & 30 June & 26 April & 9 June & 30 June \\
\hline Unsprayed & $\ldots$ & 0 & 0 & $7.0 \mathrm{a}$ & 0 & 0 & 0 \\
\hline Warning A & 3 & 0 & 0 & $0 \mathrm{~b}$ & 0 & 0 & 0 \\
\hline Warning B & 2 & 0 & 0 & $0 \mathrm{~b}$ & 0 & 0 & 0 \\
\hline Grower & 6 & 0 & 0 & $0 \mathrm{~b}$ & 0 & 0 & 0 \\
\hline Castelfranco 2007 & & 30 April & 31 May & 17 June & 30 April & 31 May & 17 June \\
\hline Unsprayed & $\ldots$ & 0 & 0 & $10.1 \mathrm{a}$ & 0 & 0 & $4.2 \mathrm{a}$ \\
\hline Warning A & 3 & 0 & 0 & $0 \mathrm{~b}$ & 0 & 0 & $0 \mathrm{~b}$ \\
\hline Warning B & 2 & 0 & 0 & $0 \mathrm{~b}$ & 0 & 0 & $0 \mathrm{~b}$ \\
\hline Grower & 6 & 0 & 0 & $0 \mathrm{~b}$ & 0 & 0 & $0 \mathrm{~b}$ \\
\hline Castelfranco 2008 & & 30 April & 10 June & 25 June & 30 April & 10 June & 25 June \\
\hline Unsprayed & $\ldots$ & 0 & $62.1 \mathrm{a}(4.3 \mathrm{a})$ & $75.8 \mathrm{a}(11.5 \mathrm{a})$ & 0 & 0 & $52.0 \mathrm{a}(2.9 \mathrm{a})$ \\
\hline Warning A & 4 & 0 & $0 \mathrm{~b}(0 \mathrm{~b})$ & $0.8 \mathrm{~b}(0 \mathrm{~b})$ & 0 & 0 & $4.3 \mathrm{c}(\operatorname{tr} \mathrm{b})$ \\
\hline Warning B & 3 & 0 & $2.0 \mathrm{~b}(\operatorname{tr} \mathrm{b})$ & $3.3 \mathrm{~b}(\operatorname{tr} \mathrm{b})$ & 0 & 0 & $26.9 \mathrm{~b}(0.5 \mathrm{~b})$ \\
\hline Grower & 7 & 0 & $0 \mathrm{~b}(0 \mathrm{~b})$ & $3.5 \mathrm{~b}(\operatorname{tr} \mathrm{b})$ & 0 & 0 & $0.0 \mathrm{c}(0 \mathrm{~b})$ \\
\hline Mandriole 2006 & & 22 April & 13 June & 27 June & 22 April & 13 June & 27 June \\
\hline Unsprayed & $\ldots$ & 0 & $53.0 \mathrm{a}(14.0 \mathrm{a})$ & $69.3 \mathrm{a}(23.9 \mathrm{a})$ & 0 & $4.7 \mathrm{a}$ & $23.3 \mathrm{a}(2.7 \mathrm{a})$ \\
\hline Warning A & 4 & 0 & $4.3 \mathrm{~b}(\operatorname{tr} \mathrm{b})$ & $20.0 \mathrm{~b}(0.4 \mathrm{~b})$ & 0 & $0 \mathrm{~b}$ & $0.7 \mathrm{c}(\operatorname{tr} \mathrm{b})$ \\
\hline Warning B & 3 & 0 & $3.2 \mathrm{~b}(\operatorname{tr} \mathrm{b})$ & $12.0 \mathrm{~b}(0.1 \mathrm{~b})$ & 0 & $0.3 \mathrm{~b}$ & $1.0 \mathrm{c}(\operatorname{tr} \mathrm{b})$ \\
\hline Grower & 6 & 0 & $0 \mathrm{c}(0 \mathrm{~b})$ & $34.0 \mathrm{~b}(\operatorname{tr} \mathrm{b})$ & 0 & $0 \mathrm{~b}$ & $9.0 \mathrm{~b}(0.1 \mathrm{~b})$ \\
\hline Mandriole 2007 & & 22 April & 16 June & 29 June & 22 April & 16 June & 29 June \\
\hline Unsprayed & $\ldots$ & 0 & 1.0 & 1.0 & 0 & 0 & 0 \\
\hline Warning A & 1 & 0 & 0 & 0 & 0 & 0 & 0 \\
\hline Warning B & 1 & 0 & 0 & 0 & 0 & 0 & 0 \\
\hline Grower & 7 & 0 & 0 & 0 & 0 & 0 & 0 \\
\hline Camerlona 2008 & & 30 April & 15 June & 2 July & 30 April & 15 June & 2 July \\
\hline Unsprayed & $\ldots$ & $3.7 \mathrm{a}$ & $37.3 \mathrm{a}(1.6 \mathrm{a})$ & $87.3 \mathrm{a}(37.3 \mathrm{a})$ & 0 & $29.3 \mathrm{a}(2.6 \mathrm{a})$ & $95.3 \mathrm{a}(38.9 \mathrm{a})$ \\
\hline Warning A & 5 & $0 \mathrm{~b}$ & $12.0 \mathrm{~b}(0.1 \mathrm{~b})$ & $14.7 \mathrm{~b}(0.2 \mathrm{~b})$ & 0 & $0.7 \mathrm{~b}(\operatorname{tr} \mathrm{b})$ & $6.7 \mathrm{~b}(0.1 \mathrm{~b})$ \\
\hline Warning B & 3 & $0 \mathrm{~b}$ & $19.3 \mathrm{~b}(0.2 \mathrm{~b})$ & $11.3 \mathrm{~b}(0.1 \mathrm{~b})$ & 0 & $2.0 \mathrm{~b}(\operatorname{tr} \mathrm{b})$ & $4.7 \mathrm{~b}(0.1 \mathrm{~b})$ \\
\hline Grower & 9 & $0.2 \mathrm{~b}$ & $6.0 \mathrm{c}(\mathrm{tr} \mathrm{b})$ & $2.0 \mathrm{c}(\operatorname{tr} \mathrm{b})$ & 0 & $0 \mathrm{~b}(0 \mathrm{~b})$ & $6.0 \mathrm{~b}(0.1 \mathrm{~b})$ \\
\hline
\end{tabular}

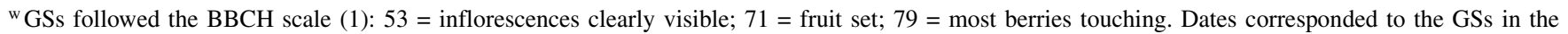
different experiments. Values followed by the same letter are not significantly different at $P=0.05$.

${ }^{\mathrm{x}}$ Disease incidence as a percentage of leaves or bunches affected by downy mildew (calculated on 100 random leaves or bunches per plot, four replicate plots per treatment). Values in parentheses indicate disease intensity as a percentage of leaf or bunch surface with downy mildew lesions; tr $\leq 0.05 \%$.

${ }^{\mathrm{y}}$ Treatments consisted of different fungicide schedules: unsprayed; Warning $\mathrm{A}=$ spraying when the warning system indicated that an infection period was predicted (or calculated a posteriori) and at least 7 days had elapsed since the previous fungicide application; Warning B $=$ spraying when an infection period was predicted (or calculated a posteriori) for an oospore cohort of at least $2 \%$ of the seasonal oospore dose; grower $=$ sprayed according the grower's schedule.

${ }^{\mathrm{z}}$ Number of sprays and dates are listed in Table 2. 
The tendency of the model to predict infection when infection does not occur has been already shown, with a false positive proportion of 0.13 (8). These false positives occur early in the season, when the host is in the earlier growth stages, or when the model starts a simulation with isolated weak rain events, or when the oosporic inoculum of the vineyard is low (8).

A second way to reduce the number of unjustified sprays in the downy mildew system is to improve the accuracy of the weather forecasts. Although the use of weather forecasts certainly adds uncertainty to model output, the use of forecasts overcomes the major disadvantage of disease warning systems based on observed weather (i.e., the latter systems are not fully predictive because they cannot give enough lead time for scheduling fungicide application and preparing equipment). Lead time is even more important when only protective fungicides are available, because they must be applied before infection occurs. This problem was recognized some time ago (25) but few attempts have been made to incorporate weather forecasts into disease forecasts $(21,22,34$, $38,50)$ despite the recent progress in forecasting weather. The inaccuracy of weather forecasts is a well-known source of error and a major factor affecting the accuracy of many disease warning systems $(2,46,55)$. The timeliness of advisories affects their practical value; however, the use of forecast weather data could potentially enhance effectiveness of warning systems $(21,47,52)$. In this warning system for grape downy mildew, inaccurate weather forecasts led to a number of unjustified alarms but never to a failure to apply a necessary spray.

The current study provides strong evidence that the warning system can be used to time the fungicide sprays needed to manage downy mildew in northern Italy. In the experiments, equivalent levels of disease were achieved with one to five sprays based on the warning system or disease model compared with six to nine sprays based on standard grower practice, confirming the goodness of the information provided by the warning system. This reduction would probably result in fewer chemical residues on produce consumed by a health-conscious public (18). In addition, this warning system can save growers as much as $300 € /$ ha in cost of fungicide applications.

Several criteria must be met before any weather-based fungicide program will be accepted by grape growers in Italy. First, growers must have assurance that risks of crop damage associated with reliance on such an approach are minimal. Grape berries are a high-value commodity, and grape growers have been minimal risk-takers in the past (3). Based on disease data from test plots, it appears that the use of the weather-based system can substantially reduce spray frequency and cost without compromising crop health and, consequently, yield and quality. Nevertheless, some growers may be more willing to apply a blanket spray than to risk making a mistake using the warning system. However, information from the warning system can help these growers to decide about whether to spray with a systemic or contact fungicide, or to decide on an additional spray when the model indicates that weather conditions have been favorable for downy mildew infection (56). If the disease model used in the warning system predicts the presence of viable sporangia and rainfall is forecast, then a protectant fungicide can be applied in advance of the potential infection period. However, if the model predicts the absence of germinated oospores or if no rain is forecast, the grower can wait for the model to evaluate a likely infection period. Then, if the model indicates that infection was likely, a fungicide with post-infection capability could be applied as soon as possible.

Another important criterion for grower adoption of the warning system is that the reduced fungicide program must be affordable. In several Italian grape-growing areas, warning services are freely supplied by governmental plant protection organizations (43). Therefore, there are no direct costs for the weather-sensing equipment and the accompanying software. The only cost the grower incurs is for an Internet connection or a mobile phone for receiving SMSs. It is unlikely that these costs will deter growers from using this technology. As noted earlier, the warning system should reduce fungicide application and associated costs. Environmental benefits should also be considered. Each saved application represents a reduction of 4.9 liters/ha in fuel consumption and a related reduction of about $12.5 \mathrm{~kg} / \mathrm{ha}$ of $\mathrm{CO}_{2}$ emissions (31).

Finally, ease-of-use is also critical for grower acceptance and use of a weatherbased warning system for downy mildew control. The warning system used in this study is easy to use in that it provides a clear management outcome: either spray or do not spray. Growers do not necessarily need to look at the raw data or calculate and interpret disease severity values to use the system.

\section{ACKNOWLEDGMENTS}

We thank M. Melandri, R. Nannini, G. Pradolesi, and M. Scannavini for managing experimental vineyards; and M. G. Tommasini for coordinating the research project, funded by the EmiliaRomagna Region.

\section{LITERATURE CITED}

1. Bleiholder, H., Weber, E., Feller, C., Hess, M., Wicke, H., Meier, U., van den Boom, T., Lancashire, P. D., Bohr, L., Hack, H., Klose, R., and Stauss, R. 2001. BBCH Monograph, 2nd ed. U. Meier, ed. Federal Biological Research Centre for Agriculture and Forestry, Germany.
2. Baldacci, E., 1947. Epifitie di Plasmopara viticola (1941-46) nell'Oltrepó Pavese ed adozione del calendario di incubazione come strumento di lotta. Atti Ist. Bot. Univ. Lab. Crittogam. Pavia 8:45-85.

3. Beresford, R. M., and Spink, M. 1992. A national disease forecasting system for apple black spot (Venturia inaequalis) in New Zealand. Acta Hortic. 313:285-296.

4. Bisson, L. F., Waterhouse, A. L., Ebeler, S. E., Walker, M. A., and Lapsley, J. T. 2002. The present and the future of international wine industry. Nature 418:696-699.

5. Borgo, M., Bellotto, D., and Zanzotto, A. 2004. Composti a base di fenamidone contro la peronospora della vite. Inf. Agrario 50:49-53.

6. Bottarelli, L., and Zinoni, F. 2002. La rete meteorologica regionale. Divulgatore 5:13-17.

7. Brunelli, A., Portillo, I., Sedda, G., and Flori, P. 2008. Studio dell'attività di recenti antiperonosporici contro Plasmopara viticola. Atti Giornate Fitopatol. 2:245-246.

8. Caffi, T., Rossi, V., Bugiani, R., Spanna, F. Flamini, L., Cossu, A., and Nigro, C. 2009. Evaluation of a model predicting primary infections of Plasmopara viticola in different grapevine-growing areas of Italy. J. Plant Pathol. 91(3):535-548.

9. Caffi, T., Rossi, V., Cossu, A., and Fronteddu, F. 2007. Empirical vs. mechanistic models for primary infections of Plasmopara viticola. IOBC/WPRS Bull. 37:261-271.

10. Egger, E., Marinelli, E., and Greco, G. 1994. Un nuovo modello gestionale per il controllo della Peronospora della vite: prime verifiche nell'ambiente viticolo aretino. Riv. Vitic. Enol. 47:15-32.

11. Ellis, M. A., Madden, L. V., and Lalancette, N. 1994. A disease forecasting program for grape downy mildew in Ohio. Pages 92-95 in: Proc. Int. Workshop Grapevine Downy Mildew Modeling, 1st. D. M. Gadoury and R. C. Seem, eds. N. Y. Agric. Exp. Stn. Spec. Rep. 68.

12. EPPO. 2000. Plasmopara viticola. Guidelines for the Efficacy Evaluation of Plant Protection Products, PP 1/31(3). European and Mediterranean Plant Protection Organization, Paris.

13. Gadoury, D. M. 1995. Controlling fungal diseases of grapevine under organic management practices. N. Y. Agric. Exp. Stn. Spec. Rep. 69:35-44.

14. Gleason, M. L. 2001. Disease-warning systems. Pages 367-370 in: Encyclopaedia of Plant Pathology, Vol. I. John Wiley \& Sons, New York.

15. Gobbin, D., Jermini, M., and Gessler, C. 2007. Strategic factors for $P$. viticola disease control In: Proc. Eur. Meet. IOBC/WPRS Working Group "Integrated Protection in Viticulture," Marsala, Italy. Abstr. Book 54.

16. Gobbin, D., Jermini, M., Loskill, B., Pertot, I., Raynal, M., and Gessler, C. 2005. Importance of secondary inoculum of Plasmopara viticola to epidemics of grapevine downy mildew. Plant Pathol. 54:522-534.

17. Gobbin, D., Pertot, I., and Gessler, C., 2003. Identification of microsatellite markers for Plasmopara viticola and establishment of high throughput method for SSR analysis. Eur. J. Plant Pathol. 109:153-164.

18. Gozzini B., Nocentini V., Orlandini S., Picchi M., Seghi L., and Viviani C. 1995. Simulation models and fungicide residuals in viticulture. Acta Hortic. 388:91-96.

19. Hill, G. K. 1990. Plasmopara Risk Oppenheim-a deterministic computer model for the viticultural extension service. Not. Mal. Piante 111:231-223.

20. Hill, G. K. 2000. Simulation of P. viticola oospore-maturation with the model SIMPO. IOBC/WPRS Bull. 23:7-8.

21. Johnson, K. B., Stockwell, V. O., and Sawyer, T. L. 2004. Adaptation of fire blight forecasting to optimize the use of biological controls. 
Plant Dis. 88:41-48.

22. Kim, K. S., Gleason, M. L., and Taylor, S. E. 2006. Forecasting site-specific leaf wetness duration for input to disease-warning systems. Plant Dis. 90:650-656.

23. Kennelly, M.M., Eugster, C., Gadoury, D. M., Smart, C. D., Seem, R. C., Gobbin, D., and Gessler, C. 2005. Contributions of oosporic inoculum to epidemics of grapevine downy mildew (Plasmopara viticola). (Abstr.) Phytopathology 94:S50.

24. Koopman, T., Linde, C. C., Fourie, P. H., and McLeod, A. 2007. Population genetic structure of Plasmopara viticola in the Western Cape Province of South Africa. Mol. Plant Pathol. 8:723-736.

25. Krause, R. A., and Massie, L. B. 1975. Predictive systems: modern approaches to disease control. Annu. Rev. Phytopathol. 13:31-47.

26. Lafon, R., and Clerjeau, M. 1988. Downy mildew. Pages 11-13 in: Compendium of Grape Diseases. R. C. Pearson and A. C. Goheen, eds. American Phytopathological Society Press, St. Paul, MN.

27. Leffelaar, P. A., and Ferrari, T. J. 1989. Some elements of dynamic simulations. Pages 19-45 in: Simulation and Systems Management in Crop Protection. R. Rabbinge, S. A. Ward, and H. H. van Laar, eds. Pudoc, Wageningen, The Netherlands.

28. Madden, L. V., and Ellis, M. A. 1988. How to develop plant disease forecasters. Pages 191208 in: Experimental Techniques in Plant Disease Epidemiology. J. Kranz and J. Rotem, eds. Springer-Verlag, New York.

29. Madden, L. V., Ellis, M. A., Lalancette, N., Hughes, G., and Wilson, L. L. 2000. Evaluation of a disease warning system for downy mildew of grapes. Plant Dis. 84:549-554.

30. Magarey, P. A., Wachtel, M. F., Weir, P. C., and Seem, R. C. 1994. A computer based simulator for rational grapevine downy mildew (Plasmopara viticola) on grape leaves. Phytopathology 78:1316-1321.

31. Massetti, L., Dalla Marta, A., and Orlandini, S. 2008. Preliminary economic evaluation of an agrometeorological system for Plasmopara viticola infections management. Acta Hortic. 803:43-50.

32. Moiraghi, G., Morando, A., and Lavezzaro, S., 2006. Vecchi e nuovi antiperonosporici sperimentati in vigneti del Piemonte. Atti Giornate Fitopatol. 2:211-218.

33. Muganu, M., Balestra, G. M., Magro, P., Pettinari, G., and Bignami, C. 2007. Susceptibility of local grape cultivars to Plasmopara viticola and response to copper compounds with low cupric salts concentration in Latium (Central Italy). Pages 373-378 in: Proc. Int. Workshop Advances Grapevine Wine Res. V. Nuzzo, eds. International Society for Horticultural Science, Belgium.

34. Murphy, A. H., and Winkler, R. L. 1987. A general framework for forecast verification. Mon. Weather Rev. 115:1330-1338.

35. Orlandini, S., Gozzini, B., Rosa, M., Egger, E., Storchi, P., Maracchi, G., and Miglietta, F. 1993. PLASMO: a simulation model for Plasmopara viticola on grapevine. EPPO Bull. 23:619-626.

36. Park, E. W., Seem, R. C., Gadoury, D. M., and Pearson, R. C. 1997. DMCAST: a prediction model for grape downy mildew development. Vitic. Enol. Sci. 52:182-189.

37. Pavan, V., Tomozeiu, R., Salvini, A., Marchesi, S., and Marsigli, C. 2003. Controllo di qualità dei dati giornalieri di temperatura minima e massima e di precipitazione. Quad. Tec. ARPA-SIM, 15:1-10.

38. Raposo, R., Wilks, D. S., and Fry, W. E. 1993. Evaluation of potato late blight forecasts modified to include weather forecasts: a simulation analysis. Phytopathology 83:103-108.

39. Rosa, M., Genesio, R., Gozzini, B., Maracchi, G., and Orlandini, S.. 1993. Plasmo: a computer program for grapevine downy mildew development forecast. Comput. Electron. Agric. 9:205-215.

40. Rossi, V., Caffi, T., Giosuè, S., and Bugiani, R. 2008. A mechanist model simulating primary infections of downy mildew in grapevine. Ecol. Model. 212:480-491.

41. Rossi, V., Giosuè, S., and Caffi T. Modelling the dynamics of infection caused by sexual and asexual spores during Plasmopara viticola epidemics. J. Plant Pathol. In press.

42. Rossi, V., Giosuè, S., Girometta, B., and Bugiani, R. 2002. Influenza delle condizioni meteorologiche sulle infezioni primarie di Plasmopara viticola in Emilia-Romagna. Atti Giornate Fitopatol. 2:263-270.

43. Rossi, V., Ponti, I., and Cravedi, P., 2000. The status of warning services for plant pests in Italy. IOBC/WPRS Bull. 30:19-29.

44. Rumbou A., and Gessler C. 2004. Genetic dissection of a Plasmopara viticola population from a Greek vineyard in two consecutive years. Eur. J. Plant Pathol. 110:379-392.

45. Rumbou A., and Gessler C. 2006. Particular structure of Plasmopara viticola populations evolved under Greek island conditions. Phytopathology 96:501-509.

46. Scherm, H., Koike, S. T., Laemmlen, F. F., and van Bruggen, A. H. C. 1995. Field evaluation of fungicide spray advisories against lettuce downy mildew (Bremia lactucae) based on measured or forecast morning leaf wetness. Plant Dis. 79:511-516.

47. Shtienberg, D., and Elad, Y. 1997. Incorporation of weather forecasting in integrated, biological-chemical management of Botrytis cinerea. Phytopathology 87:332-340.

48. Steppeler, J., Doms, G., Schättler, U., Bitzer, H. W., Gassmann, A., Damrath, U., and Gregoric, G. 2003. Meso-gamma scale forecasts using the nonhydrostaticmodel LM. Meteorol. Atmos. 115:488-504.

49. Stryzik, S. 1983. Pages 1-46 in: Modèle d'état potentiel d'infection: application a Plasmopara viticola. Association de Coordination Technique Agricole, Maison Nationale des Eleveurs.

50. Thomas, C. S., Skinner, P. W., Fox, A. D. Greer, C. A., and Gubler, W. D. 2002. Utilization of GIS/GPS-based information technology in commercial crop decision making in California, Washington, Oregon, Idaho, and Arizona. J. Nematol. 34:200-206.

51. Tran Manh Sung, C., Strizyk, C., and Clerjeau, M. 1990. Simulation of the date of maturity of Plasmopara viticola oospores to predict the severity of primary infections in grapevine. Plant Dis. 74:120-124.

52. Truxall, D. L., and Travis, J. W. 1994. Analysis of the accuracy of predicted weather data on the impact of apple disease management. (Abstr.) Phytopathology 84:1125.

53. Vercesi, A., and Liberati, D. 2001. Modelli epidemici: possibilità applicative e prospettive. Inf. Fitopatol. 51:13-18

54. Vercesi, A., Zerbetto, F., and Rho, G. 1999 Impiego dei modelli EPI e PRO nella difesa antiperonosporica del vigneto. Frustula Entomol. 22:92-97.

55. Vincelli, P. C., and Lorbeer, J. W. 1989. BLIGHT-ALERT: a weather-based predictive system for timing fungicide applications on onion before infection periods of Botrytis squamosa. Phytopathology 79:493-498.

56. Walker, S., and Haasbroek, P. D. 2007. Use of a mathematical model with hourly weather data. Pages 104-105 in: Proc. Farming Syst. Design 2007: Int. Symp. Methodologies for Integrated Analysis of Farm Production Systems Catania, Sicily, Italy. 